\title{
A narrative review of literature on the use of health and social care by older trans adults: what can United Kingdom services learn?
}

\author{
Susan Mary Benbow ${ }^{1,2 *}$ (D), Charlotte Eost-Telling ${ }^{1}$ (D) and Paul Kingston ${ }^{1}$ \\ ${ }^{1}$ Centre for Ageing Studies, University of Chester, Chester, UK and ${ }^{2}$ Older Mind Matters Ltd, \\ Manchester, UK \\ *Corresponding author. Email: drsmbenbow@gmail.com
}

(Accepted 8 January 2021; first published online 24 February 2021)

\begin{abstract}
We carried out a narrative review and thematic analysis of literature on the physical health care, mental health care and social care of trans older adults to ascertain what is known about older trans adults' contacts with and use of health and social care. Thirty papers were found: a majority originated in the United States of America. Five themes were identified: experience of discrimination/prejudice and disrespect; health inequalities; socioeconomic inequalities; positive practice; and staff training and education. The first three themes present challenges for providers and service users. Experiences of discrimination/ prejudice and disrespect over the course of their lives powerfully influence how older trans adults engage with care services and practitioners. Health and socio-economic inequalities suggest that older trans adults are likely to have greater need of services and care. The remaining two themes offer opportunities for service improvement. We conclude that more research is needed, that there is a strong argument for taking a lifecourse perspective in a spirit of cultural humility, and that contextual societal factors influence service users and providers. We identify positive trans-inclusive practices which we commend to services. More needs to be done now to make older adult services appropriate and welcoming for trans service users.
\end{abstract}

Keywords: care-giving; dementia; education; end-of-life care; mental health; older adults; stigma; transgender health

\section{Background}

The literature on the challenges faced by trans ${ }^{1}$ people when requiring health and social care has increased over the last 10 years. For example, a review and synthesis of peer-reviewed recent literature (2008-2014) about transgender health identified 116 studies in 30 countries (Reisner et al., 2016). The topics considered in the review include: access to health care and marginalisation (Ming et al., 2016; Winter et al., 2016a), clinical care considerations (Wylie et al., 2016), issues of global health burden and equity (Lo and Horton, 2016; Reisner et al., 2016), the connection between trans 
health and trans human rights (Winter et al., 2016b), how the community voice can help to understand trans health challenges (Reisner et al., 2016) and insights from over 30 countries. The literature has not specifically focused on particular age groups, rather it has taken a generic population-based position, which perhaps overlooks the subtle variance that age may bring to the trans experience: generic papers do not offer specific insights that may be unique to certain sections of the population. Age is a particularly important factor since increasing age is accompanied by physical, psychological and social changes, and services are often tailored to age. This paper focuses on what is known about older trans adults and their experiences of health and social care.

There are numerous definitions of the term transgender and its shortened form, trans. In this paper, we use the term trans and this definition:

A trans person is someone who feels that the sex they were assigned at birth (male or female) does not match or sit easily with their sense of their own gender ... It includes those who have transitioned from male to female (transgender women) or from female to male (transgender men) as well as those who do not have a typically 'male' or 'female' gender identity (non-binary). (Government Equalities Office and Gendered Intelligence, 2015: 3)

It has proved difficult to find current, comparable data of prevalence estimates within global populations, although a limited number of studies have been conducted in, for example, the United States of America (USA), the United Kingdom (UK), Belgium, the Netherlands and Singapore. Reviews of these studies (Arcelus et al., 2015; Collin et al., 2016a, 2016b; Goodman et al., 2019) have highlighted the complexity of this issue and explored how the variability within the data is influenced by factors such as study design, terminology and classification of cases, country of origin with associated cultural and legal contexts, and the date of the study. Studies focusing on surgical or hormonal gender therapy and transrelated diagnoses have estimated prevalence rates of between 1 and 30 per 100,000 people. However, studies relying on self-report suggest significantly higher rates of between 100 and 700 per 100,000 people (Collin et al., 2016a). In the UK, the Gender Identity Research and Education Society (GIRES) has updated their estimate of prevalence from 20 per 100,000 in 2007 (for people who had sought medical care for gender variance) to around 1 per cent in 2011 (although the prevalence of those seeking transition is much smaller, perhaps $0.2 \%$ of the population) (GIRES, 2011). Goodman et al. (2019) reviewed studies reporting trend data from Sweden, Serbia, the Netherlands, Spain and the USA, and in all cases found a dramatic increase in numbers of recorded trans people regardless of geographic region. Meerwijk and Sevelius (2017) concluded that the proportion of trans individuals in the USA was increasing at 0.026 per cent annually. Alongside this evidence that increasing numbers of people are identifying as trans, the general population is ageing and, as a result, the number of trans people using older adult services is expected to increase over time. It is therefore important that service providers, commissioners, funders and planners understand and address the needs of this group. Since gender reassignment is one of nine 'protected characteristics' in the Equality Act 2010, providers of health and social care services have an obligation to ensure that their services are trans-inclusive and actively tackle any impediments to access. 
In this paper, we draw on three concepts that are influential in older adult health and social care practice. One is a lifecourse perspective, which is widely accepted as a useful approach to understanding ageing and health inequalities in later life in the context of dynamic and cumulative processes across the whole of life from birth or even from conception (Foresight Mental Capital and Wellbeing Project, 2008; Fuller-Iglesias et al., 2009). A second is person-centred care which involves 'attending to the relational aspects of life inasmuch as the biological aspects' (Edvardsson, 2015). The third is cultural humility, defined as:

commitment to self-evaluation and critique, to redressing power imbalances ... and to developing mutually beneficial and non-paternalistic partnerships with communities on behalf of individuals and defined populations. (Tervalon and Murray-Garcia, 1998)

We carried out a review drawing on international literature to ascertain what is known about older trans adults' contacts with and use of health and social care services in order to inform UK research and practice.

\section{Method}

We carried out an initial search for literature in November 2018 using the stem keywords trans and old ${ }^{*}$ or age using PubMed and Medline. We selected the stem trans as being clearly defined and in common usage in the literature: this is an evolving area and there are numerous descriptors in use as people seek to describe their experience (GIRES, 2019). We reviewed the abstracts of the papers identified $(\mathrm{N}=781)$ for relevance to three inclusion criteria:

(1) Focus on trans individuals.

(2) Focus on older adults.

(3) Physical and/or mental health care and/or social care.

We excluded papers written before 2010 and non-English-language papers, and identified 21 papers which met our inclusion criteria. We excluded papers pre-2010 as Finkenauer et al. (2012) carried out a related review, and we aimed to build on that. The search was repeated in February 2020 using Medline, PubMed, PsychINFO and Google Scholar and the same stem keywords. Figure 1 sets out the results of both searches which gave a combined total of 30 papers included in this review. There were three papers by Latham and Barrett from the same project: since they complement one another and are best understood together, we have counted them as one paper for the purposes of the review.

All 30 papers were loaded into a computerised software package, NVivo, which was used to assist in thematic analysis. NVivo is a qualitative data analysis computer software package (Bazeley and Jackson, 2013; QSR International, 2016), which facilitates the organisation, storage and retrieval of data. The package also incorporates advanced data management, interrogation and visualisation tools. It may be used to complement various theoretical approaches.

The collected papers were read and re-read, allowing familiarisation with the literature, and then subjected to thematic analysis in order to explore commonalities 
and differences by identifying recurring themes and patterns (Braun and Clarke, 2006). Thematic analysis followed the following process after familiarisation; search for themes; review and clarification of themes; naming and definition of themes; and overall synthesis. Emerging themes were discussed, refined, clarified and named by research team members in partnership.

\section{Results and discussion}

Seventeen papers originated from the USA, four from Australia, four from Canada and four from Europe. One paper had authors from both the USA and UK. Most did not define older or ageing $(\mathrm{N}=16)$. Of the 14 papers that did, ten used age 50 plus as the cut-off for older age, three used age 60 plus and one used age 65 plus. Six papers described quantitative research and seven qualitative research, four were case based and five were literature reviews. The remaining papers consisted of three summary papers, two theoretical papers, two opinion pieces and one quality improvement project.

Table 1 lists the papers included in this review. Overall, the literature on older trans adults is limited. Published studies that focus on LGBT (an acronym for lesbian, gay, bi and trans) participants often include only a small number of trans participants, if any. There appears to be a tendency to use the descriptor LGBT as a catch-all, and to extrapolate findings derived from LG and B research to include trans people: Baril and Silverman (2019) refer to 'a merging of trans realities with sexual minority experiences'. The majority of recent publications originate from the USA, and UK or European research literature relevant to older trans adults is more limited. An additional complication is that studies use different cutoffs for older age or do not define the term.

Five overarching themes were identified. Three themes present challenges for health and social care services and practitioners, and the people using their services. These are: experience of discrimination/prejudice and disrespect; health inequalities; and socio-economic inequalities. Two themes suggest ways of improving services, namely positive practice in health and social care, and training and education for staff at all levels.

\section{Experience of discrimination/prejudice and disrespect}

Concerns/fears about discrimination are a recurrent theme (Ferron et al., 2010; Latham and Barrett, 2015a; Witten, 2017) and are linked to inadequate health care and possibly with behaviours that might be regarded as risky (Bachmann and Mussman, 2015; Walker et al., 2017). The context for older adults is that of lifetime experience of violence, abuse and hate crimes (Fredriksen-Goldsen et al., 2014; Porter et al., 2016).

Experiences of discrimination and disrespect within care settings range across a spectrum of experiences from insensitivity (Page et al., 2016) through 'subtle Othering' (Pang et al., 2019) to frank refusals of care (Redman, 2011) (maybe linked with denial of insurance cover; Finkenauer et al., 2012), and across a range of care settings, including gender identity services (Latham and Barrett, 2015a). Trans individuals' concerns link with previous negative experiences in 
Table 1. Papers included in the review

\begin{tabular}{|c|c|c|c|c|c|c|c|c|c|}
\hline No. & Authors & Year & $\begin{array}{l}\text { Country } \\
\text { of origin }\end{array}$ & Title & Type of paper & $\begin{array}{l}\text { Number of } \\
\text { participants }\end{array}$ & $\begin{array}{l}\text { Age of } \\
\text { participants } \\
\text { (in years) }\end{array}$ & $\begin{array}{l}\text { Culture/ethnicity } \\
\text { of participants }\end{array}$ & Comments \\
\hline 1 & Ansara & 2015 & Australia & $\begin{array}{l}\text { Challenging } \\
\text { cisgenderism in the } \\
\text { ageing and aged care } \\
\text { sector: meeting the } \\
\text { needs of older people } \\
\text { of trans and/or } \\
\text { non-binary experience }\end{array}$ & Theoretical & $\mathrm{n} / \mathrm{a}$ & $\mathrm{n} / \mathrm{a}$ & $\mathrm{n} / \mathrm{a}$ & $\begin{array}{l}\text { Aimed at aged } \\
\text { care-sector service } \\
\text { providers }\end{array}$ \\
\hline 2 & $\begin{array}{l}\text { Bachmann and } \\
\text { Mussman }\end{array}$ & 2015 & USA & $\begin{array}{l}\text { The aging population: } \\
\text { imperative to } \\
\text { uncouple sex and } \\
\text { gender to establish } \\
\text { 'gender equal' health } \\
\text { care }\end{array}$ & $\begin{array}{l}\text { Literature } \\
\text { review }\end{array}$ & $\mathrm{n} / \mathrm{a}$ & $\mathrm{n} / \mathrm{a}$ & $\mathrm{n} / \mathrm{a}$ & $\begin{array}{l}\text { Literature review } \\
\text { focused on } \\
\text { transgender medicine }\end{array}$ \\
\hline 3 & Baril and Silverman & 2019 & Canada & $\begin{array}{l}\text { Forgotten lives: trans } \\
\text { older adults living with } \\
\text { dementia at the } \\
\text { intersection of } \\
\text { cisgenderism, } \\
\text { ableism/cogniticism } \\
\text { and ageism }\end{array}$ & Theoretical & $\mathrm{n} / \mathrm{a}$ & $\mathrm{n} / \mathrm{a}$ & $\mathrm{n} / \mathrm{a}$ & $\begin{array}{l}\text { Theoretical } \\
\text { approaches to } \\
\text { managing dementia }\end{array}$ \\
\hline 4 & Bouman et al. & 2016 & Europe & $\begin{array}{l}\text { Sociodemographic } \\
\text { variables, clinical } \\
\text { features, and the role } \\
\text { of preassessment } \\
\text { cross-sex hormones in } \\
\text { older trans people }\end{array}$ & $\begin{array}{l}\text { Research - } \\
\text { quantitative }\end{array}$ & 71 & $50+$ & $\begin{array}{l}98.6 \% \text { White, } \\
1.4 \% \text { other }\end{array}$ & $\begin{array}{l}\text { Questionnaire-based } \\
\text { survey of Gender } \\
\text { Identity Clinic } \\
\text { attendees }\end{array}$ \\
\hline
\end{tabular}


Table 1. (Continued.)

\begin{tabular}{|c|c|c|c|c|c|c|c|c|c|}
\hline No. & Authors & Year & $\begin{array}{l}\text { Country } \\
\text { of origin }\end{array}$ & Title & Type of paper & $\begin{array}{l}\text { Number of } \\
\text { participants }\end{array}$ & $\begin{array}{l}\text { Age of } \\
\text { participants } \\
\text { (in years) }\end{array}$ & $\begin{array}{l}\text { Culture/ethnicity } \\
\text { of participants }\end{array}$ & Comments \\
\hline 5 & Ettner and Wylie & 2013 & $\begin{array}{l}\text { USA and } \\
\text { UK }\end{array}$ & $\begin{array}{l}\text { Psychological and } \\
\text { social adjustment in } \\
\text { older transsexual } \\
\text { people }\end{array}$ & Case based & $\mathrm{n} / \mathrm{a}$ & $\mathrm{n} / \mathrm{a}$ & $\mathrm{n} / \mathrm{a}$ & $\begin{array}{l}\text { Interventions based on } \\
\text { fictitious case } \\
\text { vignettes }\end{array}$ \\
\hline 6 & Fabbre & 2014 & USA & $\begin{array}{l}\text { Gender transitions in } \\
\text { later life: the } \\
\text { significance of time in } \\
\text { queer aging }\end{array}$ & $\begin{array}{l}\text { Research - } \\
\text { qualitative }\end{array}$ & 22 & $\begin{array}{l}50+\text { (range } \\
50+\text { to } 82 \text { ) }\end{array}$ & $\begin{array}{l}18 \text { European } \\
\text { American, } 3 \\
\text { African } \\
\text { American, } 1 \\
\text { Asian American }\end{array}$ & $\begin{array}{l}\text { Qualitative analysis of } \\
\text { interviews - applied to } \\
\text { gerontological social } \\
\text { work }\end{array}$ \\
\hline 7 & Fabbre & 2015 & USA & $\begin{array}{l}\text { Gender transitions in } \\
\text { later life: a queer } \\
\text { perspective on } \\
\text { successful aging }\end{array}$ & $\begin{array}{l}\text { Research - } \\
\text { qualitative }\end{array}$ & 22 & $\begin{array}{l}50+\text { (range } \\
50+\text { to } 82 \text { ) }\end{array}$ & As above & $\begin{array}{l}\text { Qualitative analysis of } \\
\text { interviews - applied to } \\
\text { gerontology }\end{array}$ \\
\hline 8 & Ferron et al. & 2010 & USA & $\begin{array}{l}\text { Integrated care of an } \\
\text { aging HIV-infected } \\
\text { male-to-female } \\
\text { transgender patient }\end{array}$ & Case based & 1 & 68 & Hispanic & Case study \\
\hline 9 & Finkenauer et al. & 2012 & Canada & $\begin{array}{l}\text { When injustice gets } \\
\text { old: a systematic } \\
\text { review of trans aging }\end{array}$ & $\begin{array}{l}\text { Literature } \\
\text { review (34 } \\
\text { articles) }\end{array}$ & $\mathrm{n} / \mathrm{a}$ & $\mathrm{n} / \mathrm{a}$ & $\mathrm{n} / \mathrm{a}$ & $\begin{array}{l}\text { Systematic review of } \\
\text { trans ageing - themes } \\
\text { policies and practice in } \\
\text { health care, and HIV }\end{array}$ \\
\hline 10 & $\begin{array}{l}\text { Fredriksen-Goldsen } \\
\text { et al. }\end{array}$ & 2014 & USA & $\begin{array}{l}\text { Physical and mental } \\
\text { health of transgender } \\
\text { older adults: an at-risk } \\
\text { and underserved } \\
\text { population }\end{array}$ & $\begin{array}{l}\text { Research - } \\
\text { quantitative }\end{array}$ & 174 & $50+$ & $\begin{array}{l}79.1 \% \\
\text { non-Hispanic } \\
\text { White, } 7 \% \text { Native } \\
\text { American, } 4.7 \% \\
\text { African American, } \\
3.5 \% \text { Hispanic, } \\
2.3 \% \text { multi-racial, } \\
1.7 \% \text { Pacific } \\
\text { Islander, } 1.7 \% \\
\text { other }\end{array}$ & $\begin{array}{l}\text { Survey of over fifties } \\
\text { using standardised } \\
\text { measures }\end{array}$ \\
\hline
\end{tabular}




\begin{tabular}{|c|c|c|c|c|c|c|c|c|c|}
\hline 11 & Gooren and T'Sjoen & 2018 & Europe & $\begin{array}{l}\text { Endocrine treatment } \\
\text { of aging transgender } \\
\text { people }\end{array}$ & $\begin{array}{l}\text { Literature } \\
\text { review }\end{array}$ & $\mathrm{n} / \mathrm{a}$ & $\mathrm{n} / \mathrm{a}$ & $\mathrm{n} / \mathrm{a}$ & $\begin{array}{l}\text { Summarises literature } \\
\text { on topic }\end{array}$ \\
\hline 12 & $\begin{array}{l}\text { Hoy-Ellis and } \\
\text { Fredriksen-Goldsen }\end{array}$ & 2017 & USA & $\begin{array}{l}\text { Depression among } \\
\text { transgender older } \\
\text { adults: general and } \\
\text { minority stress }\end{array}$ & $\begin{array}{l}\text { Research - } \\
\text { quantitative }\end{array}$ & 174 & $\begin{array}{l}50+\text { (range } \\
50-86)\end{array}$ & $\begin{array}{l}82 \% \\
\text { non-Hispanic } \\
\text { White, } 7.3 \% \\
\text { American Indian, } \\
\text { 4.9\% Black, } 1.8 \% \\
\text { Asian/Pacific } \\
\text { Islander }\end{array}$ & $\begin{array}{l}\text { Subset of larger LGBT } \\
\text { survey using } \\
\text { standardised measures }\end{array}$ \\
\hline 13 & Hoy-Ellis et al. & 2017 & USA & $\begin{array}{l}\text { Prior military service, } \\
\text { identity stigma, and } \\
\text { mental health among } \\
\text { transgender older } \\
\text { adults }\end{array}$ & $\begin{array}{l}\text { Research - } \\
\text { quantitative }\end{array}$ & 183 & $50+$ & $\begin{array}{l}68.0 \% \\
\text { non-Hispanic } \\
\text { White, } 32.0 \% \\
\text { People of Colour }\end{array}$ & $\begin{array}{l}\text { Subset of larger LGBT } \\
\text { survey using } \\
\text { standardised measures }\end{array}$ \\
\hline 14 & Johnson et al. & 2018 & USA & $\begin{array}{l}\text { Gay and gray session: } \\
\text { an interdisciplinary } \\
\text { approach to } \\
\text { transgender aging }\end{array}$ & $\begin{array}{l}\text { Literature } \\
\text { review }\end{array}$ & $\mathrm{n} / \mathrm{a}$ & $\mathrm{n} / \mathrm{a}$ & $\mathrm{n} / \mathrm{a}$ & $\begin{array}{l}\text { Review focused on } \\
\text { mental health care }\end{array}$ \\
\hline \multirow[t]{2}{*}{15} & Latham and Barrett & $2015 a$ & Australia & $\begin{array}{l}\text { We're people } \\
\text { first ... trans health } \\
\text { and ageing. An } \\
\text { evidence-based guide } \\
\text { to inclusive services }\end{array}$ & $\begin{array}{l}\text { Research - } \\
\text { qualitative }\end{array}$ & 15 & Range 49-79 & Not stated & $\begin{array}{l}\text { Based on interview } \\
\text { with } 15 \text { trans } \\
\text { individuals - focus on } \\
\text { health and care needs }\end{array}$ \\
\hline & Latham and Barrett & $2015 b$ & Australia & $\begin{array}{l}\text { Gender is just part of } \\
\text { who I am. Stories from } \\
\text { trans Australians: } \\
\text { exploring the } \\
\text { experiences and needs } \\
\text { of trans people for } \\
\text { health and aged care } \\
\text { services }\end{array}$ & $\begin{array}{l}\text { Research - } \\
\text { qualitative }\end{array}$ & & & & $\begin{array}{l}\text { Accounts of people's } \\
\text { stories taken from the } \\
\text { interviews above }\end{array}$ \\
\hline
\end{tabular}


Table 1. (Continued.)

\begin{tabular}{|c|c|c|c|c|c|c|c|c|c|}
\hline No. & Authors & Year & $\begin{array}{l}\text { Country } \\
\text { of origin }\end{array}$ & Title & Type of paper & $\begin{array}{l}\text { Number of } \\
\text { participants }\end{array}$ & $\begin{array}{l}\text { Age of } \\
\text { participants } \\
\text { (in years) }\end{array}$ & $\begin{array}{l}\text { Culture/ethnicity } \\
\text { of participants }\end{array}$ & Comments \\
\hline & Latham and Barrett & 2015 & Australia & $\begin{array}{l}\text { We're people first ... } \\
\text { trans health and } \\
\text { ageing: summary. An } \\
\text { evidence-based guide } \\
\text { to inclusive services }\end{array}$ & $\begin{array}{l}\text { Research - } \\
\text { qualitative }\end{array}$ & & & & $\begin{array}{l}\text { Summary of the above } \\
\text { two documents }\end{array}$ \\
\hline 16 & Llorente & 2018 & USA & $\begin{array}{l}\text { Transitioning the } \\
\text { healthcare system to } \\
\text { effectively work with } \\
\text { older transgender } \\
\text { persons }\end{array}$ & Opinion & $\mathrm{n} / \mathrm{a}$ & $\mathrm{n} / \mathrm{a}$ & $\mathrm{n} / \mathrm{a}$ & Summary and opinion \\
\hline 17 & Mahan et al. & 2016 & USA & $\begin{array}{l}\text { Drug therapy for } \\
\text { gender transitions and } \\
\text { health screenings in } \\
\text { transgender older } \\
\text { adults }\end{array}$ & Summary & $\mathrm{n} / \mathrm{a}$ & $\mathrm{n} / \mathrm{a}$ & $\mathrm{n} / \mathrm{a}$ & $\begin{array}{l}\text { Summarises what is } \\
\text { known on topic }\end{array}$ \\
\hline 18 & Marshall et al. & 2015 & Canada & $\begin{array}{l}\text { Gender dysphoria and } \\
\text { dementia: a case } \\
\text { report }\end{array}$ & Case based & 1 & 94 & British origin & Single case history \\
\hline 19 & Michael et al. & 2018 & Australia & $\begin{array}{l}\text { Supporting aged care } \\
\text { workers to understand } \\
\text { and respond to the } \\
\text { needs of transgender } \\
\text { people: a co-designed } \\
\text { quality improvement } \\
\text { initiative }\end{array}$ & $\begin{array}{l}\text { Quality } \\
\text { improvement } \\
\text { project }\end{array}$ & $\mathrm{n} / \mathrm{a}$ & $\mathrm{n} / \mathrm{a}$ & $\mathrm{n} / \mathrm{a}$ & $\begin{array}{l}\text { Quality improvement } \\
\text { project to develop } \\
\text { resources with trans } \\
\text { partners }\end{array}$ \\
\hline
\end{tabular}




\begin{tabular}{|c|c|c|c|c|c|c|c|c|c|}
\hline 20 & Page et al. & 2016 & UK & $\begin{array}{l}\text { Transgender, mental } \\
\text { health, and older } \\
\text { people: an } \\
\text { appreciative approach } \\
\text { towards working } \\
\text { together }\end{array}$ & $\begin{array}{l}\text { Research- } \\
\text { qualitative }\end{array}$ & $\mathrm{n} / \mathrm{a}$ & $\mathrm{n} / \mathrm{a}$ & $\mathrm{n} / \mathrm{a}$ & $\begin{array}{l}\text { Used appreciative } \\
\text { enquiry to identify } \\
\text { organisational vision }\end{array}$ \\
\hline 21 & Pang et al. & 2019 & Canada & $\begin{array}{l}\text { Later life care planning } \\
\text { and concerns of } \\
\text { transgender older } \\
\text { adults in Canada }\end{array}$ & $\begin{array}{l}\text { Research - } \\
\text { qualitative }\end{array}$ & 24 & Range 55-89 & $\begin{array}{l}100 \% \text { White } \\
\text { Canadians of } \\
\text { European } \\
\text { descent }\end{array}$ & $\begin{array}{l}\text { Subset of larger LGBT } \\
\text { project. Focus group } \\
\text { and interviews focused } \\
\text { on later and end of life }\end{array}$ \\
\hline 22 & Porter et al. & 2016 & USA & $\begin{array}{l}\text { Providing competent } \\
\text { and affirming services } \\
\text { for transgender and } \\
\text { gender } \\
\text { nonconforming older } \\
\text { adults }\end{array}$ & Summary & $\mathrm{n} / \mathrm{a}$ & $\mathrm{n} / \mathrm{a}$ & $\mathrm{n} / \mathrm{a}$ & $\begin{array}{l}\text { Focus on APA } \\
\text { guidelines for } \\
\text { psychological practice }\end{array}$ \\
\hline 23 & Redman & 2011 & USA & $\begin{array}{l}\text { Fear, discrimination } \\
\text { and abuse: } \\
\text { transgender elders } \\
\text { and the perils of } \\
\text { long-term care }\end{array}$ & Opinion & $\mathrm{n} / \mathrm{a}$ & $\mathrm{n} / \mathrm{a}$ & $\mathrm{n} / \mathrm{a}$ & $\begin{array}{l}\text { Opinion - based on } \\
\text { interview with trans } \\
\text { activist }\end{array}$ \\
\hline 24 & Siverskog & 2014 & Europe & $\begin{array}{l}\text { 'They just don't have a } \\
\text { clue': transgender } \\
\text { aging and implications } \\
\text { for social work }\end{array}$ & $\begin{array}{l}\text { Research - } \\
\text { qualitative }\end{array}$ & 6 & Range $62-78$ & Not stated & $\begin{array}{l}\text { Qualitative analysis of } \\
\text { interviews }\end{array}$ \\
\hline 25 & Waling et al. & 2020 & Australia & $\begin{array}{l}\text { Trans women's } \\
\text { perceptions of } \\
\text { residential aged care } \\
\text { in Australia }\end{array}$ & $\begin{array}{l}\text { Research - } \\
\text { qualitative }\end{array}$ & 10 & Range $60-75$ & Not stated & $\begin{array}{l}\text { Qualitative analysis of } \\
\text { interviews }(N=10)\end{array}$ \\
\hline 26 & Walker et al. & 2016 & USA & $\begin{array}{l}\text { An older transgender } \\
\text { woman's quest for } \\
\text { identity }\end{array}$ & Case based & 1 & 70 & Caucasian & Single case study \\
\hline
\end{tabular}


Table 1. (Continued.)

\begin{tabular}{|c|c|c|c|c|c|c|c|c|c|}
\hline No. & Authors & Year & $\begin{array}{l}\text { Country } \\
\text { of origin }\end{array}$ & Title & Type of paper & $\begin{array}{l}\text { Number of } \\
\text { participants }\end{array}$ & $\begin{array}{l}\text { Age of } \\
\text { participants } \\
\text { (in years) }\end{array}$ & $\begin{array}{l}\text { Culture/ethnicity } \\
\text { of participants }\end{array}$ & Comments \\
\hline 27 & Walker et al. & 2017 & USA & $\begin{array}{l}\text { Impact of anticipated } \\
\text { bias from healthcare } \\
\text { professionals on } \\
\text { perceived successful } \\
\text { aging among } \\
\text { transgender and } \\
\text { gender } \\
\text { nonconforming older } \\
\text { adults }\end{array}$ & $\begin{array}{l}\text { Research - } \\
\text { quantitative }\end{array}$ & 384 & $50+$ & $\begin{array}{l}91.2 \% \text { White, } \\
2.6 \% \\
\text { multi-racial, } \\
1.0 \% \text { Hispanic, } \\
0.5 \% \text { Black, } \\
0.5 \% \text { Native } \\
\text { American, } 4.2 \% \\
\text { other }\end{array}$ & $\begin{array}{l}\text { Subset of larger online } \\
\text { survey }\end{array}$ \\
\hline 28 & Warren and Steffen & 2020 & USA & $\begin{array}{l}\text { Development of a } \\
\text { transgender and } \\
\text { gender } \\
\text { nonconforming } \\
\text { language self-efficacy } \\
\text { scale for social service } \\
\text { providers working with } \\
\text { older adults }\end{array}$ & $\begin{array}{l}\text { Research - } \\
\text { quantitative }\end{array}$ & $\mathrm{n} / \mathrm{a}$ & $\mathrm{n} / \mathrm{a}$ & $\mathrm{n} / \mathrm{a}$ & $\begin{array}{l}\text { Survey of Area } \\
\text { Agencies on Aging } \\
\text { focused on developing } \\
\text { new scale }\end{array}$ \\
\hline 29 & Witten & 2014 & USA & $\begin{array}{l}\text { It's not all darkness: } \\
\text { robustness, resilience, } \\
\text { and successful } \\
\text { transgender aging }\end{array}$ & $\begin{array}{l}\text { Literature } \\
\text { review }\end{array}$ & $\mathrm{n} / \mathrm{a}$ & $\mathrm{n} / \mathrm{a}$ & $\mathrm{n} / \mathrm{a}$ & $\begin{array}{l}\text { Literature review } \\
\text { focused on } \\
\text { transgender ageing }\end{array}$ \\
\hline 30 & Witten & 2017 & USA & $\begin{array}{l}\text { Health and well-being } \\
\text { of transgender elders }\end{array}$ & Summary & $\mathrm{n} / \mathrm{a}$ & $\mathrm{n} / \mathrm{a}$ & $\mathrm{n} / \mathrm{a}$ & $\begin{array}{l}\text { Summary of what is } \\
\text { known on topic }\end{array}$ \\
\hline
\end{tabular}

Notes: n/a: not applicable. UK: United Kingdom. USA: United States of America. APA: American Psychological Association. 
health and/or social care and lead to anticipation of bias which acts as a barrier (Fabbre, 2015; Baril and Silverman, 2019), influencing trans persons both in terms of reluctance to access services (Walker et al., 2017) and in whether they are able to be open and 'come out' to health and social care practitioners (Fredriksen-Goldsen et al., 2014). Service barriers include denial of agency and gate-keeping (Fabbre, 2015; Johnson et al., 2018; Baril and Silverman, 2019). Latham and Barrett (2015b) describe rejection, stigmatisation and discrimination as being an inevitable part of being trans, and Siverskog notes that:

Earlier experiences of being closeted, shamed, and disciplined are something that one carries through life in the form of mental and physical scars, and that also have social and material consequences in later life. (Siverskog, 2014: 394)

These points are important, in that trans people's previous experiences of discrimination, including discrimination from service providers, will influence their worries about accessing and using services and how they relate to health and care practitioners and services. Internalised stigma (Siverskog, 2014; Porter et al., 2016; Johnson et al., 2018) is also relevant (for more on this issue, see Puckett and Levitt, 2015). Invisibility is a word sometimes applied to trans people within health and social care (and more widely) (Fredriksen-Goldsen et al., 2014; Siverskog, 2014; Witten, 2014, 2017; Page et al., 2016; Porter et al., 2016; Walker et al., 2016; Michael et al., 2018; Pang et al., 2019; Waling et al., 2020).

Bouman et al. (2016) use the term double discrimination, referring to the discrimination attached to being trans plus the discrimination linked with being older, although Warren and Steffen (2020) suggest that older trans adults may be more likely to attribute discrimination to gender identity than to age. Ettner and Wylie (2013) comment that the physical and sensory changes that accompany ageing may be more challenging ('poignant') for older trans adults who have transitioned late, and Fabbre (2014) makes observations on time, writing about awareness of time left to live and sense of time wasted/lost in connection with late gender transition. The awareness that time left is short may exert pressure on trans individuals to transition, whereas practitioners may take an ageist view, questioning why an individual might want to do this at an older age. Set against this, for some people later life may bring new beginnings (Pang et al., 2019). Other writers flag up the need to acknowledge intersectionality: in addition to transphobia and ageism some older trans adults will be subject to other forms of oppression, including those related to ethnicity and/or sexuality (Siverskog, 2014; Witten, 2014; Porter et al., 2016; Walker et al., 2017).

Privacy is a concern in health and social care settings (Redman, 2011; Finkenauer et al., 2012; Ansara, 2015; Walker et al., 2016; Witten, 2017; Michael et al., 2018; Pang et al., 2019) and encompasses privacy of information, space and direct aspects of care. It links to discrimination and disrespect, and also to the challenges (or anticipated challenges) of growing older, possibly becoming physically more dependent on others and being less able to maintain one's own privacy without support. This is particularly in relation to personal care-related activities of daily life, but also more broadly in relation to administrative procedures 
(Ansara, 2015) and maintenance of hormone use if someone becomes unable to manage their own medication (Latham and Barrett, 2015a).

\section{Health inequalities}

Older trans adults have been reported to have higher rates of physical ill-health, disability, obesity and lack of physical activity than older non-trans LGB adults (Fredriksen-Goldsen et al., 2014). Higher rates of psychological morbidity are also reported. Fredriksen-Goldsen et al. (2014) found older trans adults to be at higher risk of depressive symptomatology and perceived stress than older non-trans LGB adults, and Hoy-Ellis et al. (2017) found that nearly 50 per cent of trans adults aged 50+ had clinically significant depressive symptomatology in a secondary analysis of data from a large community survey in the USA. It is argued that having, historically, to hide one's gender identity, together with experiences of discrimination and social isolation, may be relevant to these higher rates of psychological morbidity (Porter et al., 2016). Witten (2017) notes that there is a lack of data on suicidality in older trans adults.

Alongside this, there are concerns about long-term implications of trans-specific treatments. Trans individuals may have undergone surgery related to their gender variance and this may have implications for their care as they grow older, e.g. Ansara (2015) notes that older adults with arthritis that limits their manual dexterity and who have undergone vaginoplasty may need assistance with vaginal dilatation. Gooren and T'Sjoen's (2018) review gives a useful account of the endocrine treatment of older trans individuals. Long-term treatment with hormones may result in physical health problems, e.g. trans women who have cardiovascular risk factors and who start on oestrogen therapy have a higher risk of cardiovascular problems and may need careful monitoring (Mahan et al., 2016; Gooren and T'Sjoen, 2018), and Mahan et al. (2016) note that testosterone can increase the risk of destabilising some psychiatric conditions, e.g. bipolar and schizoaffective disorders. Hormonal dosage may need to be adjusted as a trans person ages, whilst maintaining a dose that sustains their affirmed gender (Mahan et al., 2016; Gooren and T'Sjoen, 2018). Conditions associated with ageing may add to the complexity of treatment (Ferron et al., 2010; Bachmann and Mussman, 2015) and may introduce the possibility of drug interactions with hormonal treatments (Porter et al., 2016). Bone health is a further area of concern in older trans individuals as a consequence of long-term hormone treatment (Mahan et al., 2016).

It is interesting to note two positive findings. One study has reported that the use of cross-sex hormones amongst older trans women appeared to be associated with psychological benefits (Bouman et al., 2016), although many had obtained their hormones via the internet or privately. Also, prior military service has been found to be associated with lower levels of depressive symptomatology and higher health-related quality of life amongst older trans adults (Hoy-Ellis et al., 2017).

Screening is a further complication: appropriate health screening may be associated with the person's gender assigned at birth and may therefore be missed for administrative reasons or because of being associated with a previous gender identity (Mahan et al., 2016; Gooren and T'Sjoen, 2018; Waling et al., 2020). 
Historically, there has been a complex relationship between mental health and gender diversity/identifying as trans. In the past, being trans was itself regarded as an indicator of mental ill-health and a (psychiatric) diagnosis was needed in order to access gender-affirming treatments. However, over recent years societal attitudes have undergone a considerable shift towards understanding gender more as a spectrum, and towards separating mental ill-health from gender variance (World Professional Association for Transgender Health, 2012). Nevertheless, a history of 'gender dysphoria' may mean that older trans people are sensitive to suggestions of psychological ill-health and concerned that psychological symptoms will be attributed to their trans identity. Seeking counselling might be associated with getting a psychological diagnosis in order to access medical care, rather than as a way to access psychological help (Witten, 2014).

\section{Sub-theme: dementia}

Dementia is a condition that is identified by some authors as being of particular concern for older trans individuals (Witten, 2014; Ansara, 2015; Michael et al., 2018) and this relates to the complexity of managing dementia and providing transaffirming services to people with dementia. Page et al. (2016) list a number of potential concerns for trans people who are developing dementia: fear of being 'outed' as trans as a consequence of needing care; losing touch with one's individual gender identity; having to rely on others to express one's own gender identity; being forced into the 'wrong' gender identity (maybe reverting to birth gender); and not being treated with respect and dignity.

Four of the papers included in this review make a major contribution to this area. Latham and Barrett (2015b) include two narrative accounts from trans people living with dementia: one trans woman had transitioned a long time before moving into a care setting and prior to moving into care was dressing and living as a woman. In the home, she dressed and lived as a man. A staff member is quoted as saying that this was not the individual's choice, implying that this was the only way their family would keep links with them, and the authors raise the question of whether this is elder abuse. This narrative raises the possibility of undue influence (Peisah et al., 2009). Power imbalances can affect vulnerable adults as well as children, and age, gender and access to resources are potential factors in a power imbalance. The concept of undue influence is applicable to the abusive situation described and, in the UK, a safeguarding response would have been appropriate and consequently a police perspective introduced.

Another case in the literature involves a trans woman who developed dementia with 'subsequent gender confusion', and became unable to express a clear gender preference (Marshall et al., 2015). The next of kin was a daughter who had difficulty accepting her father's transition. The authors suggest that the best management might have been a 'gender-neutral' approach but question whether this would have been ethical. Baril and Silverman's (2019) paper contributes a theoretical analysis of possible management approaches, namely gender neutralisation; trans-affirmative stable (supporting the person's pre-dementia self-identified gender identity); trans-affirmative fluid (supporting the person's gender identity as experienced at the time); and what they refer to as a fourth paradigm. Their fourth paradigm rests on three principles: it is fluidly trans-affirmative supporting the 
changing nature of gender identity and expression, values the personhood of the individual and is age-positive, respecting the agency of the individual with dementia. It will be interesting to learn how this translates into practice. Page et al. (2016) describe an ongoing systems approach to service change in older people's mental health using appreciative inquiry and involving older trans experts engaging with mental health practitioners to describe a vision, quality standards and guidelines for the future service. Their paper suggests that they support the trans-affirmative stable approach.

\section{Socio-economic inequalities}

There is little focus in the identified papers on the social care aspects of growing older as a trans individual, although some papers are directed at a social work audience (Fabbre, 2014; Siverskog, 2014). Fabbre (2014) notes how trans individuals who transition later in life will renegotiate their social and familial relationships and the social expectations that have dominated their earlier lives: a fifth of her group described ongoing socio-economic challenges. She argues that social workers are in a position to support the growth and wellbeing of the people they work with and should do more to help, and warns against perpetuating heteronormative assumptions about identity and behaviour (Fabbre, 2015).

A key theme identified in relation to social care is possible increased reliance on formal social care services because of a lack of family/social support. Trans individuals may have been rejected by their family of origin, and they may not engage with or feel they belong with LGB communities (Porter et al., 2016). As a result, they may have limited access to informal social supports, possibly in conjunction with less financial resource, leading to potentially greater reliance on formal (or in some countries public) services. This has been identified as a concern for trans individuals as they grow older: people may fear increasing dependency and a need for assistance with personal care and other activities of daily living either in their own home or in a long-term care setting. These concerns might also encompass communal housing options for older adults (Walker et al., 2017), some of which due to their faith-based foundations may introduce even greater complexity into an already challenging situation. Witten (2014) comments on the fear of potential abuse by care-givers and some of her interviewees considered de-transitioning for reasons of safety.

In terms of economic challenges, in some economies a lack of insurance to fund care is a concern (Ferron et al., 2010; Finkenauer et al., 2012; Waling et al., 2020), and this is in a context of possible historical economic instability for older trans adults who may have experienced discrimination and barriers in education and employment, and who are at increased risk of poverty and homelessness (Finkenauer et al., 2012).

\section{Sub-theme: care-giving}

We found that older trans individuals as care-givers were conspicuous by their absence from the identified literature, despite reports in the broader LGBT literature that LGB and T individuals may be more likely to take on a caring role than non-LGBT individuals (Shiu et al., 2016). Where people rely on friends as 
care-givers (Hines, 2007), those friends are likely to be of a similar age - and may be limited in their ability to provide long-term care and support because of their own health issues.

\section{Positive practice in health and social care}

Taking a lifecourse perspective involves aiming to understand individuals in terms of their family and personal history, prior life experiences, psycho-social context, broad socio-historical context and relational context, all of which affect physical and mental health, and wellbeing in later life (Siverskog, 2014; Witten, 2014; Latham and Barrett, 2015b; Porter et al., 2016; Walker et al., 2016, 2017). Health and social care systems are often perceived as inflexible by those who use them, and a lifecourse perspective to some extent mitigates inflexibility. However, questioning by practitioners needs to be respectful, sensitive, non-intrusive, sympathetic to the possibility/likelihood of adverse prior experiences and proportionate to the context (Porter et al., 2016). Porter et al. (2016: 377) recommend an attitude of cultural humility and an accepting non-judgemental stance on the part of providers/practitioners, and define cultural humility in terms of a relational stance that is other-oriented in relation to aspects of cultural identity most important to the individual concerned.

Other suggestions for positive practice include the following: avoiding unnecessary and/or intrusive questioning; attention to how staff use language (e.g. avoiding the use of incorrect pronouns and names); gender-neutral restroom facilities; agencies displaying material to show that they aspire to be trans friendly; policies appropriately recognising non-biological kin; and both cultivating and advertising links with local community groups (Siverskog, 2014; Ansara, 2015; Bachmann and Mussman, 2015; Latham and Barrett, 2015b; Porter et al., 2016; Walker et al., 2017). Table 2 summarises some of the positive/affirming practice suggestions in the literature.

Future planning is an aspect of positive practice in relation to physical and mental health and social care. Fredriksen-Goldsen et al. (2014) found that older trans people in the USA were less likely to have put in place arrangements for Power of Attorney and less likely to have written wills. Latham and Barrett (2015) stress the need to document future health-care and personal care wishes in an advance care plan as early as possible in order to ensure that one's rights are upheld. This is particularly important in relation to end-of-life care: there is a major anxiety for some people about being mis-gendered at end of life and/or after death, and narrative accounts of families/others imposing their own wishes and not respecting what an individual wanted (Latham and Barrett, 2015, 2015a; Llorente, 2018). Witten (2014) asserts that some trans individuals consider self-euthanasia or suicide as an alternative to the possible indignities they fear at the end of life. Planning ahead may be a way of ensuring that one's wishes (including those related to gender identity) are respected at the end of life. Legal issues include advance directives, Powers of Attorney and wills (Witten, 2014; Porter et al., 2016).

\section{Training and education of staff at all levels}

Training and education contribute to positive practice and were a prominent theme in the literature reviewed. 
Table 2. Examples of positive practice

\begin{tabular}{|c|c|}
\hline Area & Suggested actions \\
\hline Administrative & $\begin{array}{l}\text { - Ensure use of an individual's preferred name and pronoun } \\
\text { - EPR designates preferred name and pronoun } \\
\text { - Gender-inclusive terms used, e.g. partners }\end{array}$ \\
\hline Environmental & $\begin{array}{l}\text { - Gender-inclusive restrooms } \\
\text { - Gender-inclusive materials, e.g. posters, magazines in shared/ } \\
\text { waiting areas } \\
\text { - Gender-inclusive material on website } \\
\text { - Privacy of interview/treatment rooms }\end{array}$ \\
\hline $\begin{array}{l}\text { Treatment/ } \\
\text { management }\end{array}$ & $\begin{array}{l}\text { - Non-intrusive and respectful questioning by practitioners } \\
\text { - Maintaining a list of trans-accepting/affirming resources/ } \\
\text { clinicians/practitioners in an area and referring people to them } \\
\text { when necessary } \\
\text { - Information about available community resources } \\
\text { - Person-centred/lifecourse/biographical treatment approach } \\
\text { - Access to care co-ordination when appropriate }\end{array}$ \\
\hline Staff training & $\begin{array}{l}\text { - Including gender diversity in equality training for staff } \\
\text { - Advertising that staff are trained, e.g. on website } \\
\text { - Encouraging staff to reflect on their own biases/prejudices }\end{array}$ \\
\hline Policies & $\begin{array}{l}\text { - Recognising non-biological kin and/or carers } \\
\text { - Protection from biological kin who disrespect an individual's } \\
\text { gender identity } \\
\text { - Recruiting staff from diverse communities } \\
\text { - Co-design of policies with a wide range of service users including } \\
\text { gender-diverse persons }\end{array}$ \\
\hline $\begin{array}{l}\text { Service design/ } \\
\text { development }\end{array}$ & $\begin{array}{l}\text { - Co-design approach to service design and training at all levels } \\
\text { involving a wide range of service users, including gender-diverse } \\
\text { individuals }\end{array}$ \\
\hline Other & $\begin{array}{l}\text { - Awareness programmes for residential care services } \\
\text { - Future planning actions, e.g. Powers of Attorney, wills }\end{array}$ \\
\hline
\end{tabular}

Note: EPR Electronic Patient Record.

In the past, trans people have, not uncommonly, been put in the tricky position of educating health and social care professionals with whom they work (Siverskog, 2014; Latham and Barrett, 2015a, 2015b; Porter et al., 2016). They may have had to come out as trans to health and social care providers despite not seeing their trans status as relevant to their health and/or social care needs (Latham and Barrett, 2015b). Porter et al. (2016) point out that a third of US and Canadian medical school curricula require zero clinical hours on LGBT health care.

It is not surprising then that training and educating staff is widely regarded as both helpful and important in the literature reviewed and this applies across health and social care (Fredriksen-Goldsen et al., 2014; Siverskog, 2014; Mahan et al., 
2016; Walker et al., 2017; Waling et al., 2020). Training is understood to indicate, as a minimum, that agencies recognise the importance of gender diversity and acknowledge the need to train their staff in order to provide non-discriminatory care for trans service users. At best it indicates that older trans service users will receive respectful affirming care. Whether training changes attitudes and behaviours and how it changes practice remain to be established.

The literature identifies a need for training and education in a number of areas, including: current definitions, concepts, terminology and trans issues relevant to practice (Bachmann and Mussman, 2015; Warren and Steffen, 2020); knowledge and skills regarding trans-inclusive care across all health and social care staff and professions (Finkenauer et al., 2012; Waling et al., 2020); a lifecourse/biographical approach to care (Porter et al., 2016); organisational leadership (Latham and Barrett, 2015a); and co-design approaches to involving trans service users at all levels (Michael et al., 2018).

\section{Conclusions}

Limitations of this review include the following: non-English papers were excluded; most of the literature is North American; some papers have few participants; and many of the papers underrepresented certain groups, including trans people of colour. These limitations have implications with regard to the application and generalisability of our findings and support the need for further research. Despite these limitations, we draw conclusions in three broad areas: research and teaching/training; practice; and societal.

With regard to research, we located relatively few papers specifically focused on older trans adults and fewer papers still originated from the UK. There is a need for more research in this area to inform training and clinical practice. We suggest that priority research topics might include investigating what services for older adults can do differently and evaluating what difference changes make to people using those services. Although training is commonly regarded as helpful and important, there is less clarity about how and when training should be carried out and what difference it makes. How are doctors, nurses, social care professionals and others who are training currently informed and educated about issues affecting older trans adults and their care and support? Involving older trans people in training is likely to be more powerful than professionals running training on their own. In reviewing these papers, we found powerful accounts of people's experiences in social and health care related to gender variance. It remains to be established whether training changes people's prejudices, attitudes and practice, or whether people learn that their attitudes are unacceptable and hide them more effectively.

Specific areas for further research are care-giving, dementia and end-of-life care. The literature suggests that there are differences in care-giving amongst older trans adults and for them to have equal access to supportive services (which may be more necessary when they are estranged from family) these differences need to be better understood. There is also evidence that older trans people have specific concerns about dementia and end-of-life care: to provide good and equitable care, organisations providing services need to ensure that their staff are aware of these and that the concerns are addressed appropriately. 
With regard to practice, the practical suggestions in the literature for combating prejudice and making people feel more welcome are a useful starting point. Older adult health and social care services are familiar with the concept of person-centred care (Nolan et al., 2006; Brooker, 2007; Bridges et al., 2009; Edvardsson, 2015) and the benefits of taking a lifecourse perspective (Jones et al., 2019). The evidence for, and argument in favour of, an approach of cultural humility is strong, and fits with these established philosophies. The trans-inclusive practices identified in Table 2 fit with these approaches. Staff who connect with the concerns and experiences of older trans people are likely to provide more appropriate and tailored care.

The reviewed literature highlights the complex relationship between mental health and gender variance, reflecting the uncomfortable relationship between psychiatric diagnosis and societal attitudes and beliefs, and the possible assumptions made in relation to cause and effect. Furthermore, it highlights particular physical health-care issues and the need to acknowledge the power of historical experiences that may still influence people many years later. It raises questions about how best to provide person-centred health and social care for older trans people. Our view is that all services should be equipped to provide appropriate care but there may also be a need for some specialist health and social care. There is little to guide us on this in the existing literature.

Of course, it is impossible to separate what is happening at the level of service provision from the broader societal changes taking place. How these broader changes in understanding of and acceptance of gender variance are influencing service users and service providers, both organisationally and as individuals, is unclear. The evidence shows there is still much work to be done to ensure that older trans people have access to culturally appropriate and welcoming services, and we commend the trans-inclusive positive practices identified in Table 2 as useful starting points for services.

Financial support. This literature review was part of a service improvement project commissioned by Age UK Cheshire and funded by Cheshire West and Chester Council's Equality and Diversity Fund.

Conflict of interest. The authors declare no conflicts of interest.

Ethical standards. The paper reports a literature review so ethical approval was not required.

\section{Note}

1 The authors have chosen to use the style 'trans' in this paper in response to comments from service users.

\section{References}

Ansara YG (2015) Challenging cisgenderism in the ageing and aged care sector: meeting the needs of older people of trans and/or non-binary experience. Australasian Journal on Ageing 34, supplement 2, 14-18.

Arcelus J, Bouman WP, Van Den Noortgate W, Claes L, Witcomb G and Fernandez-Aranda F (2015) Systematic review and meta-analysis of prevalence studies in transsexualism. European Psychiatry 30, 807-815.

Bachmann GA and Mussman B (2015) The aging population: imperative to uncouple sex and gender to establish 'gender equal' health care. Maturitas 80, 421-425.

Baril A and Silverman M (2019) Forgotten lives: trans older adults living with dementia at the intersection of cisgenderism, ableism/cogniticism and ageism. Sexualities. doi:10.1177/1363460719876835.

Bazeley P and Jackson K (2013) Qualitative Data Analysis with NVIVO, 2nd Edn. London: Sage. 
Bouman WP, Claes L, Marshall E, Pinner GT, Longworth J, Maddox V, Witcomb G, Jimenez-Murcia S, Fernandez-Aranda F and Arcelus J (2016) Sociodemographic variables, clinical features, and the role of preassessment cross-sex hormones in older trans people. Journal of Sexual Medicine 13, 711-719.

Braun V and Clarke V (2006) Using thematic analysis in psychology. Qualitative Research in Psychology 3, 77-101.

Bridges J, Flatley M, Meyer J and Nicholson C (2009) Best Practice for Older People in Acute Care Settings (BPOP): Guidance for Nurses (2009). Available at http://nursingstandard.rcnpublishing.co.uk/shared/ media/pdfs/CaringForOlderPeople.pdf.

Brooker D (2007) Person-centred Dementia Care: Making Services Better. London: Jessica Kingsley Publishers.

Collin L, Goodman M and Tangpricha V (2016a) Worldwide prevalence of transgender and gender nonconformity. In Ettner R, Monstrey S and Coleman E (eds), Principles of Transgender Medicine and Surgery. New York, NY: Routledge, pp. 30-49.

Collin L, Reisner SL, Tangpricha V and Goodman M (2016b) Prevalence of transgender depends on the 'case' definition: a systematic review Journal of Sexual Medicine 13, 613-626.

Edvardsson D (2015) Notes on person-centred care: what it is and what it is not. Nordic Journal of Nursing Research 35, 65-66.

Ettner R and Wylie K (2013) Psychological and social adjustment in older transsexual people. Maturitas 74, 226-229.

Fabbre VD (2014) Gender transitions in later life: the significance of time in queer aging. Journal of Gerontological Social Work 57, 161-175.

Fabbre VD (2015) Gender transitions in later life: a queer perspective on successful aging. The Gerontologist 55, 144-153.

Ferron P, Young S, Boulanger C, Rodriguez A and Moreno J (2010) Integrated care of an aging HIV-infected male-to-female transgender patient. Journal of the Assocation of Nurses in AIDS Care 21, 278-282.

Finkenauer S, Sherratt J, Marlow J and Brodey A (2012) When injustice gets old: a systematic review of trans aging. Journal of Gay \& Lesbian Social Services 24, 311-330.

Foresight Mental Capital and Wellbeing Project (2008) Final Project Report. London: Government Office for Science.

Fredriksen-Goldsen KI, Cook-Daniels L, Kim H-J, Erosheva EA, Emlet CA, Hoy-Ellis CP, Goldsen J and Muraco A (2014) Physical and mental health of transgender older adults: an at-risk and underserved population. The Gerontologist 5, 488-500.

Fuller-Iglesias H, Smith J and Antonucci TC (2009) Theories of aging from a life-course and life-span perspective: an overview. Annual Review of Gerontology and Geriatrics 29, 3-25.

Gender Identity Research and Education Society (GIRES) (2011) The Number of Gender Variant People in the UK - Update 2011. Available at https://uktrans.info/attachments/article/197/Prevalence2011.pdf.

Gender Identity Research and Education Society (GIRES) (2019) Terminology. Available at https://www. gires.org.uk/resources/terminology/.

Goodman M, Adams N, Corneil T, Kreukels B, Motmans J and Coleman E (2019) Size and distribution of transgender and gender nonconforming populations: a narrative review. Endocrinology and Metabolism Clinics 48, 303-321.

Gooren LJ and T'Sjoen G (2018) Endocrine treatment of aging transgender people. Reviews in Endocrine and Metabolic Disorders 19, 253-262.

Government Equalities Office and Gendered Intelligence (2015) Providing Services for Transgender Customers: A Guide. Available at https://www.gov.uk/government/uploads/system/uploads/attachment_data/file/484857/Providing_services_for_transgender_customers-a_guide.pdf.

Hines S (2007) Transgendering care: practices of care within transgender communities. Critical Social Policy 27, 462-486.

Hoy-Ellis CP and Fredriksen-Goldsen KI (2017) Depression among transgender older adults: general and minority stress. American Journal of Community Psychology 59, 295-305.

Hoy-Ellis CP, Shiu C, Sullivan KM, Kim H-J, Sturges AM and Fredriksen-Goldsen KI (2017) Prior military service, identity stigma, and mental health among transgender older adults. Gerontologist 57, supplement 1, S63-S71. 
Johnson K, Yarns BC, Abrams JM, Calbridge LA and Sewell DD (2018) Gay and gray session: an interdisciplinary approach to transgender aging. American Journal of Geriatric Psychiatry 26, 719-738.

Jones NL, Gilman TE, Cheng TL, Drury SS, Hill CV and Geronimus AT (2019) Life course approaches to the causes of health disparities. American Journal of Public Health 109, S48-S55.

Latham JR and Barrett C (2015) We're People First ... Trans Health and Ageing: Summary. An Evidence-based Guide to Inclusive Services. Australian Research Centre in Sex, Health and Society, La Trobe University, Melbourne, Australia.

Latham JR and Barrett C (2015a) We're People First ... Trans Health and Ageing. An Evidence-based Guide to Inclusive Services. Available at https://www.latrobe.edu.au/_data/assets/pdf_file/0004/814792/TransAgeing-And-Aged-Care-Project.pdf.

Latham JR and Barrett C (2015b) Gender Is Just Part of Who I Am. Stories from Trans Australians: Exploring the Experiences and Needs of Trans People for Health and Aged Care Services. Available at https://grai.org.au/wp-content/uploads/2020/05/Latham-Barrett-2015-Trans-Narratives_WEB.pdf.

Llorente MD (2018) Transitioning the healthcare system to effectively work with older transgender persons. American Journal of Geriatric Psychiatry 26, 739-740.

Lo S and Horton R (2016) Transgender health: an opportunity for global health equity. Lancet 388, 316-318.

Mahan RJ, Bailey TA, Bibb TJ, Fenney M and Williams T (2016) Drug therapy for gender transitions and health screenings in transgender older adults. Journal of the American Geriatrics Society 64, 2554-2559.

Marshall J, Cooper M and Rudnick A (2015) Gender dysphoria and dementia: a case report. Journal of Gay \& Lesbian Mental Health 19, 112-117.

Meerwijk EL and Sevelius JM (2017) Transgender population size in the United States: a meta-regression of population-based probability samples. American Journal of Public Health 107, e1-e8.

Michael J, Walsh L, Goldner S, Healy K, Draper R, Elder K and McLeod K (2018) Supporting aged care workers to understand and respond to the needs of transgender people: a co-designed quality improvement initiative. Diversity and Equality in Health and Care 15, 116-121.

Ming LC, Hadi MA and Khan TM (2016) Transgender health in India and Pakistan. Lancet 388, 26012602.

Nolan M, Brown J, Davies S, Nolan J and Keady J (2006) The Senses Framework: Improving Care for Older People Through a Relationship-centred Approach. Getting Research into Practice (GRiP) Report No 2. Project Report. Available at http://shura.shu.ac.uk/280/1/PDF_Senses_Framework_Report.pdf.

Page S, Burgess J, Davies-Abbott I, Roberts D and Molderson J (2016) Transgender, mental health, and older people: an appreciative approach towards working together. Issues in Mental Health Nursing 37, 903-911.

Pang C, Gutman G and de Vries B (2019) Later life care planning and concerns of transgender older adults in Canada. International Journal of Aging \& Human Development 89, 39-56.

Peisah C, Finkel S, Shulman K, Melding P, Luxenberg J, Heinik J, Jacoby R, Resberg B, Stoppe G, Barker A, Firmino H and Bennett H (2009) The wills of older people: risk factors for undue influence. International Psychogeriatrics 21, 7-15.

Porter KE, Brennan-Ing M, Chang SC, Dickey LM, Singh AA, Bower KL and Witten TM (2016) Providing competent and affirming services for transgender and gender nonconforming older adults. Clinical Gerontologist 39, 366-388.

Puckett JA and Levitt HM (2015) Internalized stigma within sexual and gender minorities: change strategies and clinical implications. Journal of LGBT Issues in Counseling 9, 329-349.

QSR International (2016) NVivo 11 Pro for Windows. Available at http://download.qsrinternational.com/ Document/NVivo11/11.3.0/en-US/NVivo11-Getting-Started-Guide-Pro-edition.pdf.

Redman D (2011) Fear, discrimination and abuse: transgender elders and the perils of long-term care. Aging Today, March-April. Available at https://www.asaging.org/blog/fear-discrimination-and-abusetransgender-elders-and-perils-long-term-care.

Reisner SL, Poteat T, Keatley J, Cabral M, Mothopeng T, Dunham E, Holland CE, Max R and Bara SD (2016) Global health burden and needs of transgender populations: a review. Lancet 388, 412-436.

Shiu C, Muraco A and Fredriksen-Goldsen K (2016) Invisible care: friend and partner care among older lesbian, gay, bisexual, and transgender (LGBT) adults. Journal of the Society of Social Work Research 7 , $527-546$. 
Siverskog A (2014) 'They just don't have a clue': transgender aging and implications for social work. Journal of Gerontological Social Work 57, 386-406.

Tervalon M and Murray-Garcia J (1998) Cultural humility versus cultural competence: a critical distinction in defining physician training outcomes in multicultural education. Journal of Health Care for the Poor and Underserved 9, 117-125.

Waling A, Lyons A, Alba B, Minichiello V, Barrett C, Hughes M, Fredriksen-Goldsen K and Edmonds S (2020) Trans women's perceptions of residential aged care in Australia. British Journal of Social Work 50, 1304-1323.

Walker C, Cohen H and Jenkins D (2016) An older transgender woman's quest for identity. Journal of Psychosocial Nursing 54, 31-38.

Walker R, Powers S and Witten T (2017) Impact of anticipated bias from healthcare professionals on perceived successful aging among transgender and gender nonconforming older adults. LGBT Health $\mathbf{4}$, 427-433.

Warren AR and Steffen AM (2020) Development of a transgender and gender nonconforming language self-efficacy scale for social service providers working with older adults. Journal of Applied Gerontology 39, $555-560$.

Winter S, Diamond M, Green J, Karasic D, Reed T, Whittle S and Wylie K (2016a) Transgender people: health at the margins of society. Lancet 388, 390-400.

Winter S, Settle E, Wylie K, Reisner S, Cabral M, Knudson G and Baral S (2016b) Synergies in health and human rights: a call to action to improve transgender health. Lancet 388, 318-321.

Witten T (2014) It's not all darkness: robustness, resilience, and successful transgender aging. LGBT Health $1,24-33$.

Witten T (2017) Health and well-being of transgender elders. Annual Review of Gerontology and Geriatrics 37, 27-41.

World Professional Association for Transgender Health (2012) Standards of Care for the Health of Transsexual, Transgender and Gender-nonconforming People. Available at https://www.wpath.org/ media/cms/Documents/SOC\%20v7/Standards\%20of\%20Care_V7\%20Full\%20Book_English.pdf.

Wylie K, Knudson G, Khan SI, Bonierbale M, Watanyusakul S and Baral S (2016) Serving transgender people: clinical care considerations and service delivery models in transgender health. Lancet 388, 401-411.

Cite this article: Benbow SM, Eost-Telling C, Kingston P (2022). A narrative review of literature on the use of health and social care by older trans adults: what can United Kingdom services learn? Ageing \& Society 42, 2262-2283. https://doi.org/10.1017/S0144686X21000039 